\title{
Language Anxiety Among Adult Learners in Uitm Sarawak
}

\author{
Siti Huzaimah Binti Sahari ${ }^{1}$,
}

Aiza Binti Johari2

Affidah Binti Morni ${ }^{3}$

\begin{abstract}
Language anxiety is one of the factors that needs to be considered in learning and teaching second or foreign language. Language anxiety can be defined as the feelings of uneasiness, worry, nervousness, self-doubt, frustration and apprehension (Brown, 2001) experienced by non-native speakers when learning or using a second or foreign language. Learners respond to language anxiety differently. This study investigates the language anxiety levels and coping strategies applied by adult learners of UiTM Sarawak in using English as a medium of instruction. The subjects of the study involved those between 45 to 50 years of age. The data collection was carried out through the distribution of questionnaires and semi-structured interviews. The results from the study show that the adult learners have different levels of language anxiety and they have also adopted several strategies in coping with their anxiety. The conclusion of the study presents suggestions and recommendations on ways in handling anxiety in both teaching and learning second language.
\end{abstract}

Keywords: language anxiety, adult learners, UiTM Sarawak

\section{Introduction}

What is language anxiety? Language anxiety is a condition where the learners feel anxious, panic, worried when conversing in the language which is not their first language or mother tongue. The lack of confidence, a reluctant to speak, even insomnia in some cases are some of the familiar symptoms (Ellis, 2008). One particular area addressed by many researchers (Maclntyre,1995; Horwitz, Horwitz \& Cope, 1986; Young, 1991 and Sparks \& Ganschow, 1995), falls under the area of affective factors on how the learner feels emotionally towards the language (Scovel, 1991).

Program Pensiswazahan Guru Besar or better known as PKPGB, is one of the programs offered in Universiti Teknologi MARA Sarawak... The program is designed to provide an opportunity for the Guru Besar or Principals from primary schools who are still in DG 32 or DG 34 (diploma scale) to further their studies in Bachelor Degree in Education. The age ranges from 40 to 50 years old.

As the English language is the medium of instruction for all courses in UiTM Sarawak, this has caused the students or candidates to question their ability in coping with English as the medium in classes and assessments. Hence, there is a need to analyze the students, especially the adult learners on their language anxiety level in using English as their second language. The analysis will give a clear view of the anxiety levels and this will help in term of coping mechanism as well as teaching methods.

\section{The Objectives}

The objectives of this paper are to identify the language anxiety levels among adult students in UITM Sarawak. Besides that, the respondents were also interviewed ignored to investigate their coping mechanism and learning strategies. In addition, some effective methods in teaching and learning English as a second language will also discussed.

\section{Research Methodology}


Questionnaire and semi-structured interview are used to collect data. The data from questionnaire is analyzed using simple frequency count and the answers from interviews are tabulated and gathered in identifying the students language anxiety in using English language as a medium of instruction.

The questionnaire is adopted and adapted from SLAs by Dr Carter. In order to identify the levels of anxiety, 14 questions were asked and the respondents would rank their levels based on Likert scale from 1 to 5 as; 1 as Not at all anxious, 2 as Slightly anxious, 3 as Moderately anxious, 4 as Very anxious and 5 as Extremely anxious.

The questions are:

The English lecturer asks me a question in English in class.

Speaking informally to my English teacher out of class.

Taking part in group discussion in class.

Taking part in a role-play or dialogue in front of my class.

Giving an oral presentation to the rest of the class.

When asked to contribute to a formal discussion in class.

When asked to contribute to an informal discussion in class.

Asking for advice in English from a lecturer / supervisor in my university.

Talking in English to administrative staff of my faculty.

A lecturer / supervisor from my faculty of study asks me a question in English

A lecturer / supervisor from other faculties of study asks me a question in English

Taking part in a conversation out of class with people whom I think speak better English than me.

Starting a conversation out of class with a friend or colleague whom I think speaks better English than me.

An English speaker I do not know asks me questions.

The questions in the interview were mainly focus on what are the coping mechanism that they adopted in order to lessen their anxiety. The respondents were also asked what will they do in order to improve their language proficiency.

\section{Data Analysis}

This section will show the results of the questionnaire based on each question. The results are shown using bar graphs.

\section{Chart 1}

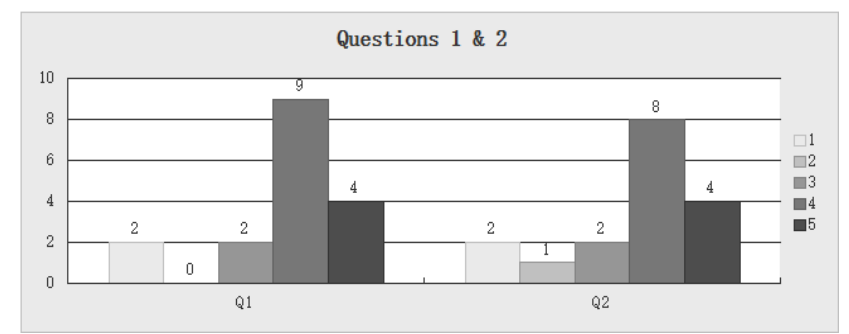


Question 1 : The English lecturer asks me a question in English in class.

Question 2 : Speaking informally to my English teacher out of class.

\section{Chart 2}

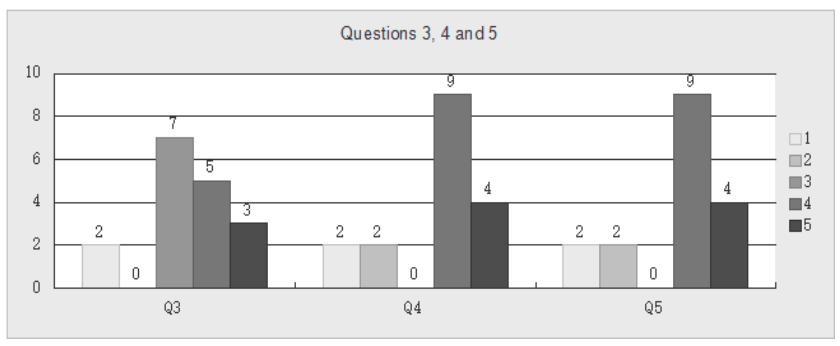

Question 3: Taking part in group discussion in class.

Question 4: Taking part in a role-play or dialogue in front of my class.

Question 5: Giving an oral presentation to the rest of the class.

\section{Chart 3}

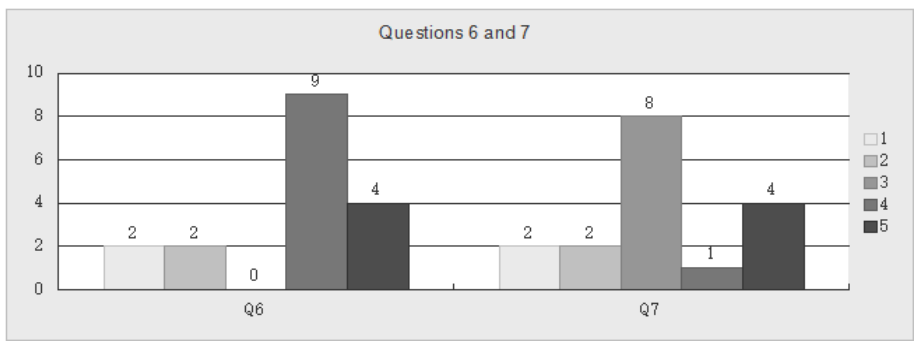

Question 6: When asked to contribute to a formal discussion in class.

Question 7: When asked to contribute to an informal discussion in class.

\section{Chart 4}

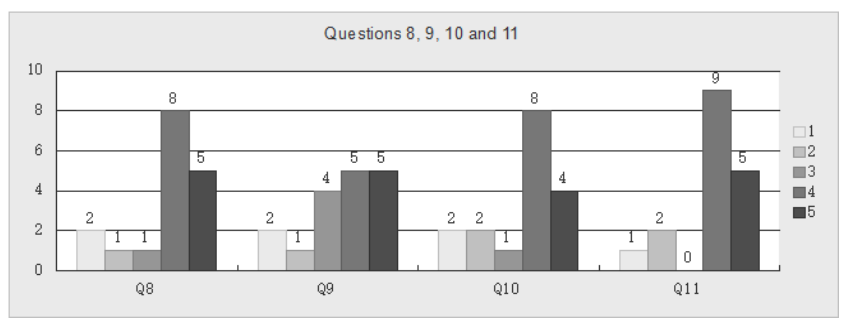

Question 8: Asking for advice in English from a lecturer / supervisor in my university.

Question 9: Talking in English to administrative staff of my faculty. 
Question 10: A lecturer / supervisor from my faculty of study asks me a question in English

Question 11: A lecturer / supervisor from other faculties of study asks me a question in English

\section{Chart 5}

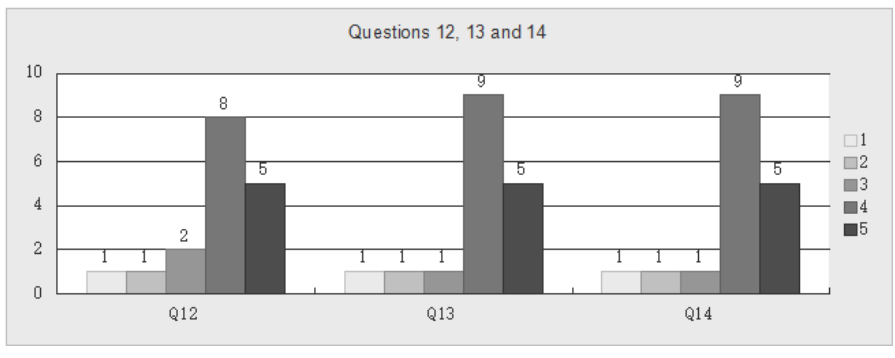

Question 12: Taking part in a conversation out of class with people whom I think speak better English than me.

Question 13: Starting a conversation out of class with a friend or colleague whom I think speaks better English than me.

Question 14: An English speaker I do not know asks me questions.

\section{Interview results}

When asked what normally they do when they feel anxious and nervous, these are some of the answers.

They will try to calm down and talk themselves to feel relax.

They will ask help from other classmates if they are in class.

They will force and encourage themselves to speak English because they know their purpose for being in university.

When asked what will they do to improve their English language proficiency.

They will speak in English more.

They will read more English materials.

They will listen and watch more English programs.

They will ask questions if they do not understand.

They will refer to dictionary and install e-dictionary in their smart phones.

\section{Conclusion, Discussion And Recommendation}

As can be seen by the charts it can be concluded that the level of anxiety differs based on the situations. Chart 1, talking to English lecturer in formal and informal situations caused high level of anxiety among students. In Chart 2, participating in group discussion and talking among themselves does not caused much anxiety among students and doing presentations and role play in front of the class caused high level of anxiety among most students. In Chart 3 , when contributing in discussion in class; the anxiety levels differ depend on the situation. Formal discussion will cause high anxiety level and informal discussion will not cause high level of anxiety. In Chart 4, talking to administrative staff affect the students' anxiety level in moderate stage while talking to lecturer or supervisors caused high level of anxiety. In the last chart, Chart 5 
indicates that talking to somebody who they think speaks better English compared to them or an English speaker affect them greatly in their anxiety levels. In conclusion, in most situations this group of adult students has a high level of language anxiety.

Some students have developed their own coping mechanisms in dealing with this anxiety problem (Dornyei, 2005). Having no other choices but to face their anxiety and practising the language were the only options the learners have. Despite all these , there are still some methods or techniques that lecturers (or language teachers) can help in reducing the anxiety level (Chew and Chui, 2012). To add, Chao (2003) suggested that anxiety and language learning may serve as a guide for language educators to increase their understanding of language from the perspective of the learner.

Making fun or insulting the adult learners is one of the things which can definitely hinder their efforts to converse and participate in class. Working many years in the Malay Language environment, the learners may find it difficult and challenging when using English as a medium of instruction in their study. Hence, as mentioned by Zheng (2008) having full understanding of the students' situation will provide insights into how educators can develop suitable interventions to decrease language anxiety among second language learners.

Other than that, to build confidence in students in using the language is the key motivation to them. Students, no matter what ages they are, need to be nurtured and encouraged in using the language (Ehrman and Oxford, 1990). Using the second language in their classroom, doing assignments and seating for exams affect their confidence in their own ability. Thus, it is important for lecturers to build and boost their confidence level. Trang, Mobi and Baldauf (2012) too suggested that students should be informed about the importance of learning English so that strong motivation can be developed and hence, students can reconfirm their awareness on the importance of English.

In planning and conducting class for adult learners, lecturers or teachers can refer to Knowles (1984) andragogy. There 5 basic principles suggested by Knowles.

\section{a.Self concept- dependent to self-directed}

Adults learners need to feel resposible in their lives and decisions, so it is important to make them feel that they have control over their learning. Thus, a good rapport and peer relationship with their instructors or lecturers will give sense of control by being able to participate and communicate with the lecturers. Self-assessment, multiple options and subtle support are essential in their learning.

\section{b.Adult Learner Experience}

Activities in language class need to be in par with their experience in life. Discussion and sharing of experience is important before introducing them to the new concept or theory. Mistakes or weaknesses should be treated as learning experience.

\section{c. Readiness to learn}

It is said that as a person matures the readiness to learn will be more oriented towards the developmental tasks of their social roles. Thus, it is important to incorporate the element of their social roles into the lesson, tasks, activities and lesson plan.

\section{d. Orientation to Learning-}

Activities and approaches used in class in learning and teaching English language need to be revolve around problems solving based on real life situation. This will change subject centeredness to problem centeredness, which will ease students understanding towards the functins of the language.

\section{e. Motivation to learn}

In 1984, Malcolm Knowles added this fifth concept of adult learners which is the motivation to learn is internal motivation. Based on this concept, encouragement from lecturers and instructors will help to build their instrinsic motivation to learn.

Last but not least, anxiety can be marshaled into a positive force. Students' anxiety, uncertainty and discomfort can become a catalyst to learn more (Hallinger, 1998). Convincing the students that the mistakes and errors that they are making, or 
going to make will make them speak better as they are learning every time they make mistakes, is one of the ways to best deal with their anxiety. Their anxiety should and can be channeled to improve their language (Richardson, 1996).

In conclusion, students of second language will experience anxiety, in one way or another. This is because learning the second language can be difficult for them. Students should develop coping mechanism in facing this anxiety (Robinson, 2006). Lecturers or teachers should form understanding on this anxiety and help them feel confident and encourage their participation in class.

\section{Reference}

[1] Brown, H.D. (2001) Teaching by Principles: An Interactive Approach to Language Pedagogy. Second Edition. White Plains, NY: Pearson Education

[2] Chao, C.-T. (2003). Foreign language anxiety and emotional intelligence: A study of EFL students in Taiwan. Unpublished doctoral dissertation, Texas University, Texas, United States.

[3] Chew, F.P. \& Chui, J.H. (2012) Beliefs about ESL Learning among Secondary School Students in Terengganu, Malaysia. International Journal of Research in Economics and Social Sciences. Vol. 2 (2) p44-63

[4] Cook, V. (1991) Second Language Learning and Second Language Teaching. Oxford: Blackwell

[5] Dornyei, Z. (2005) The Psychology of the Language Learner: Individual Differences in Second Language Acquisition. Mahwah, $\mathrm{NJ}$ : Lawrence Erlbaum

[6] Ehrman, M. E., \& Oxford, R. L. (1990). Adult learning styles and strategies in an intensive training setting. The Modern Language Journal, 74, p311-326.

[7] Ellis, R. (1994). The Study of Second Language Acquisition. Oxford: Oxford University Press.

[8] Ellis, R. (2008) Learner Beliefs and Language Learning. Asian EFL Journal. Vol. 10 (4) p7-25

[9] Hallinger, P. (1998) Educational Change in Southeast Asia: The Challenge of Creating Learning Systems. Journal of Educational Administration. Vol. 36 (5) p492-509

[10] Horwitz, E. (2001) Language Anxiety and Achievement. Annual Review of Applied Linguistics 21:112-126.

[11] Horwitz, E., Horwitz, M. and Cope,J. (1986) Foreign Language Classroom Anxiety. The Modern Language Journal 70:125132.

[12] Kearsley, G (2010) Andragogy (M. Knowles). The Theory Into Practice Database. Retrieved from http://tip.psychology.org

[13] Knowles, M (1984) Andragogy in Action. San Francisco: Jossey-Bass

[14] Macintyre, P. (1995) How Does Anxiety Affect Second Language Learning? A Reply to Sparks and Ganschow. The Modern Language Journal 79: 90-99.

[15] Richardson, V. (1996) The Role of Attitudes and Beliefs in Learning to Teach. In J. Sikula, T.J. Butter \& E. Guyton (Eds.), Handbook of research on teacher education (p102-119). New York: Macmillan

[16] Robinson, P. (2005). Aptitude and second language acquisition. Annual Review of Applied Linguistics. Vol 25, p 46-73.

[17] Scovel, T. (1991) The Effect of Affect on Foreign Language Learning: a Review of the Anxiety Research. In Language Anxiety: From Theory and Research to Classroom Implications, ed. by Elaine Horwitz and Dolly Young. Englewood Cliffs, $\mathrm{NJ}$ : Prentice Hall.

[18] Sparks, R., and Leonore,G. (1995) A Strong Inference Approach to Causal Factors in Foreign Langauge Learning: a Response to Maclntyre. The Modern Language Journal 79:235-244.

[19] Trang, T.T.T., Moni, K. and Beldauf (Jr.), R.B. (2012) Foreign Language Anxiety and its effects on students' determination to study English: to abandon or not to abandon. TESOL in Context, S3

[20] Young, D. (1991) The Relationship Between Anxiety and Foreign Language Oral Proficiency Ratings. In Language Anxiety: From Theory and Research to Classroom Implications, ed. by Elaine Horwitz and Dolly Young. Englewood Cliffs, NJ: Prentice Hall.

[21] Zheng,Y. (2008) Anxiety and Second /Foreign Language Learning Revisited. Canadian Journal for New Scholars in Education. Vol 1 (1) 